\title{
Editorial RES 1/2021
}

\author{
TAMARA GRDZELIDZE*
}

For the Life of the World. Toward a Social Ethos of the Orthodox Church (FLW) was published in March 2020 and has already attracted attention among the Orthodox and beyond. The much-needed discussion in the Orthodox Church on the social engagement of the Church has immediately gained momentum and become a popular topic of reflection.

$F L W$ was created in the bosom of the Greek Orthodox Archdiocese of America, with a considerable participation of lay theologians. In every Orthodox context, Christians will benefit greatly from a reflection on this text since it raises awareness on the urgency of the Church's social engagement. The lack of comprehensive orthodox teaching on social issues has been at the centre of discussions outside of the Church but inside the Orthodox Church, it has been impossible so far to respond to these urgent questions as one ecclesial body. Concerns raised in the document focus on dialogue, what the Church and the world tell one another. As more Orthodox are involved in critical assessment of the is-
Das Dokument Für das Leben der Welt-Das Sozialethos der orthodoxen Kirche (FLW) wurde im März 2020 publiziert und hat nicht nur in der Orthodoxie Aufmerksamkeit gefunden, sondern auch darüber hinaus. Die so überfällige Diskussion über das soziale Engagement der Orthodoxen Kirche hat hier einen wichtigen Anstoß erhalten und wird vielerorts aufgegriffen.

$F L W$ ist innerhalb der griechisch-orthodoxen Erzdiözese der USA entstanden und wurde in bedeutendem Maße auch von Laientheologen mitgestaltet. Dieser Text ist ein Gewinn für alle orthodoxen Christinnen und Christen, da er die Bedeutung des Sozialen Dienstes der Kirche zum Bewusstsein bringt. Das Fehlen einer umfassenden orthodoxen Lehre zu sozialen Fragen wurde von Außenstehenden immer wieder bemängelt, aber innerhalb der Orthodoxen Kirche war es bisher unmöglich, gemeinsam zu dringenden Fragen Stellung zu nehmen. Das Dokument betont die Notwendigkeit des Dialogs zwischen Kirche und Welt. Je mehr Orthodoxe in kritischer Beurteilung auf die Fragen

\footnotetext{
* Tamara Grdzelidze, PhD, Orthodox theologian from Georgia, served in the Secretariat of Faith and Order Commission of the World Council of Geneva (2001-2013), served as Ambassador of Georgia to the Holy See (2014-2018), currently teaches at the Religious Department of Ilia State University in Tbilisi, Georgia.
} 


\section{Editorial}

sues raised in FLW more chances will appear for these issues to find their way into the teaching of the Orthodox Church.

$F L W$ is the second document of this kind, the first similar document was issued by the Russian Orthodox Church (ROC), Bases of the Social Concept of the Russian Orthodox Church, circulated in the Christian jubilee year 2000, and evoked a great interest among theologians as a longawaited document regarding social issues. There is a vast amount of written commentary on the Russian document, which became an object of praise as the first Orthodox attempt to tackle social issues ecclesially as well as of profound criticism because of its political implications and allegiance with national interests. Comparisons between the two texts will be unavoidable in the future as both derive from local contexts. A huge divergence in their self-understandings of being local will define every conversation regarding the two texts: the Russian text shows signs of representing a church with strong aspirations for national and international hegemony; FLW deliberately avoids such self-identification, but rather tries to find ways of building bridges through dialogue between the Church and the world.

The current issue of RES offers interesting evaluations of some key aspects of the Church's life in the world: Nikolaos Asproulis writes on how the document envisages eingehen, die $F L W$ anspricht, desto mehr können diese Fragen dann auch in der Lehre der Orthodoxen Kirche Eingang finden.

FLW ist das zweite Dokument seiner Art. Das erste wurde im Jahr 2000 von der Russischen Orthodoxen Kirche unter dem Titel Grundlagen der Soziallehre der Russischen Orthodoxen Kirche herausgegeben. Als ein lange erwartetes Dokument fand es ein entsprechendes Interesse unter Theologen. Viel wurde darüber geschrieben, sowohl lobend als erstem orthodoxen Versuch, sich sozialen Fragen zu stellen - als auch äußerst kritisch, weil es politisch geprägt ist und sich nationalen Interessen verpflichtet weiß. Ein Vergleich der beiden Dokumente wird unabdingbar sein, da beide aus bestimmten lokalen Kontexten heraus entstanden sind. Ein großer Unterschied besteht im Selbstverständnis dessen, was diese lokale Bindung je bedeutet: der russische Text lässt durchscheinen, dass er in einer Kirche mit einer starken Tendenz zur Hegemonie auf nationaler und internationaler Ebene entstanden ist; $F L W$ hingegen vermeidet ein solches Selbstverständnis und versucht vielmehr, Brücken des Dialogs zwischen der Kirche und der Welt zu schlagen.

Der vorliegende Band von RES bietet interessante Analysen zu Aspekten dessen, was den Ort der Kirche in der Welt betrifft. Nikolaos Asproulis beschreibt, wie das Dokument die Kirche in einer pluralisti- 
the Church's position in a pluralistic society, where every citizen observes the culture of human rights and democratic principles and the church "has to assume every aspect of human life" in social, political and existential terms. It is encouraging to learn that the document is grounded in the Orthodox tradition while it avoids being self-referential. The article highlights the need for sustaining a dialogue between Christianity and "the political dimension of public life". Suggesting to avoid idealization of any specific political ideology, Asproulis points out the importance of theologians addressing the ongoing challenges and problems of modernity. He finds that the document fits into this pattern of thought, being politically unbiased yet addressing the urgent needs of our present time. The document, we learn, avoids the triumphalism that often hinders the Orthodox encounter with the modern world. Contemporary Orthodox Christians, on the other hand, need hermeneutics which will allow them to maintain an ongoing dialogue with the world without compromising Orthodox teaching, and always "strive against evil" (\$4).

In order to sustain an open and unbiased dialogue between the Church and the world, the document suggests adopting the liberating Orthodox ethos, expressed as a loving communion with one another and the whole of God's Creation $(\$ 3)$. In the spirit of the Orthodox schen Gesellschaft verortet, in der die Bürger die Menschenrechte und demokratische Prinzipien achten, wobei sich die Kirche „aller Aspekte des menschlichen Lebens annimmt", in sozialer, politischer und existentieller Hinsicht. Ermutigend ist die Feststellung, dass das Dokument in der orthodoxen Tradition verwurzelt ist, ohne selbstreferentiell zu sein. Der Aufsatz betont die Bedeutung eines Dialogs zwischen dem Christentum und „der politischen Dimension des öffentlichen Lebens". Keine einzelne politische Ideologie sollte idealisiert werden; vielmehr geht es darum, dass sich die Theologen mit den immer neuen Herausforderungen und Problemen der Moderne auseinandersetzen. Asproulis kommt zum Schluss, dass das Dokument dieser Anforderung genügt, weil es unparteiisch ist und sich gleichzeitig den dringenden Fragen der Gegenwart stellt. Es vermeidet den Triumphalismus, der der Begegnung der Orthodoxie mit der Moderne oft im Wege steht. Orthodoxe Christen brauchen allerdings auch eine Hermeneutik, die dem Dialog mit der Welt angemessen ist, ohne die orthodoxe Lehre in Gefahr zu bringen, und die immer auch „gegen das Böse kämpft" (\$ 4).

Um einen offenen und unbefangenen Dialog zwischen der Kirche und der Welt zu fördern, weist das Dokument auf das befreiende orthodoxe Ethos hin, das als Gemeinschaft der Liebe untereinander und mit dem Ganzen von Gottes Schöpfung 


\section{Editorial}

findings regarding environmental issues, the document notes the special responsibility of Christians towards the salvation of the divine Creation.

Asproulis points out the importance of the reception of secularism, which the document highlights in an optimistic way. This, however, can become true only through freeing itself from "slavish and unholy submission to earthly power and complicity in its evils" ( $\$ 13)$, because the Church and state relations rely on dialectic between earthly history and the age to come.

Encouragement to fight against poverty leads towards the need for solidarity and just systems, which is always a difficult point to argue politically. It seems Christians are still looking for more adequate practices in order to adjust the Christian teaching on economic equality and justice to contemporary political agendas.

Samuele Bignotti in his article "Ecumenical Bridges between Orthodox and Catholic Sides: Comparison between Fratelli Tutti of Pope Francis and For the Life of the World. Toward a Social Ethos of the Orthodox Church Signed by the Ecumenical Patriarch Bartholomew" juxtaposes two documents from the perspective of Catholic-Orthodox relations and dialogue. Both documents, we read, help Christians to not be afraid of pluralism but rather cooperate with it. FLW shows readiness to admit failures in the past, as well as "provides a roadmap for umschrieben wird. Die Orthodoxie ist für Umweltfragen besonders sensibilisiert, und darum betont das Dokument auch die Verantwortung der Christinnen und Christen für die Bewahrung der göttlichen Schöpfung.

Asproulis weist darauf hin, dass das Dokument die Dimension der Weltlichkeit aus einer optimistischen Sicht aufgreift, obwohl dies nur dann gültig ist, wenn auch von der Befreiung „,on der sklavischen und unheiligen Unterordnung unter irdische Mächte und von der Komplizenschaft mit dem Bösen" ( $\$ 13)$ gesprochen wird. Die Beziehung zwischen Kirche und Staat steht in einer Dialektik von irdischer Geschichte und erwartetem Äon.

Der notwendige Kampf gegen die Armut führt zur Forderung nach Solidarität und gerechten Systemen; was dies politisch bedeutet, ist allerdings nicht einfach auszudrücken. Noch völlig offen ist die Suche nach der geeigneten Weise, wie die christliche Lehre bezüglich wirtschaftlicher Gleichheit und Gerechtigkeit in die gegenwärtige politische Agenda einfließen könnte.

Samuele Bignotti vergleicht in seinem Beitrag mit dem Titel „Ökumenische Brücken zwischen Orthodoxie und Katholizismus" das sozialethische Dokument des Ökumenischen Patriarchats mit der Enzyklika Fratelli Tutti von Papst Franziskus. Beide Texte - so Bignotti - helfen den Christen, sich nicht vor dem Pluralismus zu fürchten, sondern ihn 
reconciling contemporary issues with the wisdom and beauty of the Orthodox spiritual tradition", Bignotti is quoting from an article by Fr. John Chryssavgis.

Perhaps an initial impression from drawing similarities between the two texts is that addressing social issues will bear similar fruits in two Christian communities. This impression cannot be entirely true because of the position and role of the two leaders. Pope Francis grounded his encyclical on the rich Catholic tradition for social teaching as well as on his previous encyclicals - Evangelii Gaudium (2013) and Laudato si' (2015), the magisterium, but Patriarch Bartholomew blesses a pioneering text based on the rich orthodox tradition. The latter is just a contribution to building of social teaching of the Orthodox Church.

For the Life of the World has already attracted the Orthodox communities worldwide but to reach ecclesial reception through its discernment extra ecclesia is a huge challenge (to which the current issue is an excellent contribution). Channels between intra ecclesia and extra ecclesia in the Orthodox world, perhaps, are strongest and fairest where the document was created, in the USA. It gives less credit to the assumption of the author that this text carries a potential to serve directly "as a bridge for dialogue between Orthodox and Catholics". Yes, it may serve in some ways as a vielmehr mit einzubeziehen. In $F L W$ wird die Bereitschaft ausgedrückt, Fehler der Vergangenheit zuzugeben, und er „zeigt einen Weg, wie gegenwärtige Fragen mit der Weisheit und Schönheit der geistlichen Tradition der Orthodoxie versöhnt werden", wie Bignotti es mit den Worten aus einem Aufsatz von John Chryssavgis ausdrückt.

Man könnte denken, dass sich ein Vergleich zwischen den beiden Texten vor allem daran messen sollte, ob sie in den beiden christlichen Gemeinschaften ähnliche Früchte hervorbringen. Dem ist aber nicht so, weil die Rolle der jeweils führenden Personen eine andere ist. Die Enzyklika von Papst Franziskus steht in der reichen Tradition der katholischen Soziallehre, und in seinem Lehramt baut er zudem auf die beiden vorangehenden Enzykliken auf, Evangelii Gaudium von 2012 und Laudato si' von 2015. Der Text, den sich Patriarch Bartholomäus zu eigen machte, ist hingegen eine Pioniertat, die sich auf die reiche orthodoxe Tradition stützt, aber worin eine Soziallehre erst noch entstehen muss.

Für das Leben der Welt hat zwar in orthodoxen Kreisen viel Aufmerksamkeit erfahren, aber der Weg hin zu einer kirchlichen Rezeption ist eine große Herausforderung. Die Verbindung zwischen innerkirchlichen Vollzügen und außerkirchlichen Beziehungen ist, was die Orthodoxie betrifft, in den USA - dem Entstehungsort des Dokuments - 


\section{Editorial}

"bridge for dialogue" but will be difficult to see $F L W$ as a reference point in formal dialogue between the two Churches. Addressing documents of the local Orthodox Churches at inter-confessional dialogues would be a great initiative, similar to that by which papal encyclicals draw wisdom from local episcopal conferences (while some of these encyclicals address wider constituency than the Catholic Church). But again, ecclesiological divergence between the two churches may not support this particular initiative to be put into practice at once.

The author notes the difficulty in comparing the first Orthodox text on social teaching of the ROC with the one under discussion; the former is much more focused on local agenda while the latter is much more open to Orthodox Christians world-wide. It is true that "open-mindedness" of $F L W$ credits it with an opportunity to be embraced in the Christian world, even beyond the Orthodoxy, but this is not because of the global role of the Ecumenical Patriarchate. The See of Constantinople, let us say, "symbolizes global Orthodoxy" in certain matters, that is the unity of the local autocephalous churches. I would add that the figure of Patriarch Bartholomew, his open and fraternal attitude towards fellow Christians, his personal contribution to issues of the Anthropocene in the age of climate change, his inter-religious endeavour, indeed, make him a fig- am stärksten. Hat es - wie der Autor des Aufsatzes vermutet - das Potenzial, „eine Brücke im Dialog zwischen Orthodoxie und Katholizismus" zu sein? Das wäre zwar denkbar, aber es ist schwer vorstellbar, dass $F L W$ zum Referenzpunkt in den formellen Dialogen zwischen den beiden Kirchen werden könnte. Es wäre zwar sehr wünschenswert, dass Dokumente aus orthodoxen Ortskirchen in die interkonfessionellen Dialoge einfließen, ähnlich wie auch päpstliche Enzykliken Ideen lokaler Bischofskonferenzen aufgreifen. Aber die unterschiedliche ekklesiologische Struktur dürfte diesem Prozess wohl im Wege stehen.

Der Autor benennt die Schwierigkeit, FLW mit dem ersten orthodoxen Dokument zu sozialen Fragen, demjenigen der russischen orthodoxen Kirche, zu vergleichen; letzteres ist viel stärker an lokalen Fragen interessiert, während ersteres sich an die weltweite Orthodoxie richtet. Diese Offenheit würde dafür sprechen, dass der Text in weiteren Kreisen und sogar über die Orthodoxie hinaus rezipiert wird; dies ist aber nicht an die Position des Ökumenischen Patriarchats gebunden. Der Sitz von Konstantinopel ist in gewisser Beziehung „das Symbol für die weltweite Orthodoxie" und damit für die Einheit der autokephalen Lokalkirchen. Diese Rolle wird durch die Persönlichkeit von Patriarch Bartholomäus noch unterstrichen, durch seine offene und brüderliche Haltung gegenüber anderen Christen, seinen persönlichen 
ure "symbolizing global Orthodoxy". But the Orthodox understanding of ecclesial leadership represents a complex mix of synodality and primacy, therefore authorities of primacy in Catholicism and Orthodoxy are of different natures.

Bignotti poses an interesting question to answer, whether these two texts assist the Orthodox and Catholic Christians to adopt the same lifestyle. He manages to answer positively since both texts share the Christian attitude of being in the world but not of the world (John 17).

From inter-confessional perspectives revealed in $F L W$ we move to inter-religious encounter (with some insights also for inter-confessional dialogue), Serafim Seppälä finds resources in the text to juxtapose Islam and the patristic approach. The author starts by identifying the authority of the argumentation in the document. To no one's surprise, it is largely a patristic heritage, "three out of four references", as he says, quote from patristic texts. The author notes the difficulty of the Orthodox Church to work out a comprehensive approach towards "the other" which causes their division regarding ecumenism. Seppälä criticizes the document's approach to Protestant tradition in which he unites the See of Canterbury with "the other Protestant Churches" and notes their unbalanced treatment. According to the Orthodox text, it seems, the Anglican tradition is not fully asso-
Beitrag zu Fragen des Anthropozäns in einer Zeit des Klimawandels, seine interreligiösen Initiativen. So ist er tatsächlich zu einem „Symbol der weltweiten Orthodoxie" geworden, allerdings im Rahmen einer Ekklesiologie, die sich in einem komplexen Ineinander von Synodalität und Primat ausdrückt. Kirchliche Autorität ist bei Katholiken und Orthodoxen von unterschiedlicher Art.

Bignotti stellt zudem die interessante Frage, ob die beiden Texte orthodoxe und katholische Christinnen und Christen zu einem ähnlichen Lebensstil anleiten. Er kommt zu einer bejahenden Antwort, da sich beide daran orientieren, dass eine Haltung des Glaubens sich darin ausdrückt, in der Welt aber nicht von der Welt zu sein (Joh. 17).

Der Aufsatz von Serafim Seppälä führt von der interkonfessionellen zur interreligiösen Begegnung, wie sie in FLW beschrieben wird. Der Autor sieht darin die Möglichkeit, den Islam und die patristische Denkweise miteinander ins Gespräch zu bringen. Vorerst einmal identifiziert er, mit welchen Bezügen die Argumentation des Dokuments gestützt wird: drei Viertel der Zitate entstammen den Kirchenvätern. Seppälä benennt die Schwierigkeit der Orthodoxen Kirche, eine gemeinsame und umfassende Haltung gegenüber dem „Anderen“ zu definieren, woraus dann gegensätzliche Einstellungen in Bezug auf die Ökumene resultieren. Kritisch zu bemerken seien die un- 


\section{Editorial}

ciated with the Protestant Churches because of its rather unique tradition. The Protestant Churches per se, definitely, need more serious attention and this, hopefully, will be corrected in the future. In the United States churches of the Protestant tradition are vibrant and growing and have also a great tradition of defending human dignity while witnessing their faith to the world.

A special interest towards Islam is natural for a document of the Patriarchate with headquarters in Turkey. Today officially Turkey is a secular state with no official state religion but in recent years Turkey introduced some unexpected changes in favour of Islam, such as converting Hagia Sophia into a mosque.

Employing the language of universal virtues in inter-religious conversations seems clichéd to Seppälä; it is diplomatic, lacking concreteness and will not take the conversation to any place of theological co-operation. In fact, Seppälä points out, $F L W$ does not offer any theological reflections regarding Christian-Islam collaboration even though it stresses the importance of reaching peace and understanding.

Examination of the earliest sources on Islam in the Christian East - those are John Damascene and Theodore Abu Qurrah - by FLW seem irrelevant to inter-religious dialogue. These early sources were concerned with prioritising Christianity over Islam and cannot provide ausgeglichenen Aussagen zum Protestantismus, etwa wenn der Sitz von Canterbury mit den ,anderen protestantischen Kirchen" verbunden wird, allerdings ohne die anglikanische Tradition in ihrer Einzigartigkeit ganz als Teil der protestantischen Kirchen zu sehen. Der Protestantismus würde jedenfalls mehr Aufmerksamkeit verdienen. Gerade in den USA hat er eine lange und lebendige Tradition, er ist im Wachstum und kennt auch den Einsatz für die Verteidigung der Menschenrechte zusammen mit dem Zeugnis des Glaubens vor der Welt.

Das Interesse für den Islam versteht sich von selbst, da das Patriarchat seinen Sitz in der Türkei hat. Offiziell ist die Türkei ein säkularer Staat, aber in den vergangenen Jahren hat die Regierung einige unerwartete Änderungen zugunsten des Islam eingeführt, worunter die Nutzung der Hagia Sophia als Moschee.

Im Zusammenhang mit den interreligiösen Begegnungen von universellen Tugenden zu reden erscheint Seppälä etwas klischeehaft, diplomatisch und abstrakt. In $F L W$ fehle an diesem Punkt die theologische Begründung für eine christlich-islamische Zusammenarbeit, so wichtig auch der gemeinsame Einsatz für Frieden und Verständigung sein mag.

Es scheint, als ob eine Untersuchung der ältesten christlichen Quellen zum Islam - derjenigen von Johannes Damaszenus und von Theodor Abu Qurrah - für $F L W$ ohne Relevanz für den interreligiösen Dialog 
material for a common ground between the two religions. The same awkwardness applies to pointing out parallelisms, "matching details" in Christianity and Islam, which often have different functions and meanings. Islam, in fact, "explicitly denies most of the fundaments of Christianity such as crucifixion, resurrection and divinity of Christ." Criticism in this respect should be taken seriously by those who wish to say more within the platform inaugurated by the $F L W$.

Nicolas Kazarian explores a theme of inter-faith dialogue in the document in relation with the rise of nationalism during the second half of the 19th and 20th cc. The Orthodox were forced to deal with pluralism through historical events taking place in the Russian Empire, Turkey, the Balkans, the Soviet Union and the ex-Soviet states. To make a comprehensive account of the Orthodox treatment of pluralism according to these complex and violent processes is a huge challenge which the author confirms by saying that the Orthodox show "a very different understanding of interfaith relations and dynamics that differ according to time and location." In this context Kazarian mentions the damage brought by ethno-religious conflicts and territorial disputes as a result of the failed peaceful negotiations. Kazarian justly casts doubt on the relevance between Orthodoxy and Huntington's theory of the clash of civilizations. FLW, in- sei. In diesen Quellen ging es um die Priorität des Christentums gegenüber dem Islam, und deshalb bilden sie keine gemeinsame Basis für die beiden Religionen. Eine ähnliche Unbeholfenheit zeigt sich dort, wo Parallelen zwischen Christentum und Islam angeführt werden, die aber bei genauerem Hinsehen unterschiedliche Funktionen und Bedeutung haben. Tatsächlich ist es so, dass der Islam „die meisten Fundamente des Christentums ausdrücklich ablehnt, wie etwa die Kreuzigung, die Auferstehung und die Göttlichkeit Christi“. Wer die Anstöße, die FLW gegeben hat, aufgreifen und weiterführen will, muss die kritischen Beobachtungen zu diesem Thema ernst nehmen.

Nicolas Kazarian stellt eine Verbindung zwischen dem Dialog in Glaubensfragen und dem aufkommenden Nationalismus in der zweiten Hälfte des 19. und im 20. Jahrhundert her. Geschichtliche Ereignisse im russischen Reich, in der Türkei, auf dem Balkan und in der Sowjetunion zwangen die Orthodoxie dazu, sich mit dem Pluralismus auseinanderzusetzen. Diese Haltung im Kontext komplexer und teils gewaltsamer Prozesse umfassend darzustellen ist allerdings schwierig, denn die Orthodoxie kannte „sehr unterschiedliche Haltungen gegenüber anderen Glaubensgemeinschaften, je nach Zeit und Ort". Weil - wie Kazarian zeigt - die Friedensverhandlungen misslangen, haben diese ethnisch-religiösen und territorialen Konflikte viel Schaden 


\section{Editorial}

stead, promotes a dialogue between the Orthodox and other Christians at every level of the life in or outside the Church, as "a reflection of the dialogue between God and humanity: it is initiated by God and conducted through the divine Logos (dia-logos), our Lord and Saviour Jesus Christ" $(\$ 54)$. The document encourages the Orthodox mediation for building bridges in a pluralistic society. A great deal of support in this direction is a fresh outlook on secularism which, undoubtedly, is a modern ideology but has an ample potential for becoming either authoritarian or reasonably liberal $(\$ 80)$.

The author confirms the status of the document by saying that it is a tool to support the social engagement of the Orthodox Church so that this engagement contributes to the transformation of the world.

Prospective reflections from the Orthodox and non-Orthodox on the theme of the social engagement in pluralistic societies, especially in places where the de facto church and state relations differ from the de jure status, are of the utmost importance.

Apart from these four articles focused on the major theme of the issue, Jan Dominik Bogataj's contribution tackles a dialogue between ages. "Conversion as Transformation of the Heart: Guardini's Existential Interpretation of Augustine's Confessions" brings into discussion some very interesting and distant topics such as Augustine and Ro- angerichtet. Huntingtons Theorie vom Zusammenprall der Zivilisationen ist allerdings in Bezug auf die Orthodoxie kaum hilfreich. FLW sucht den Dialog der Orthodoxie mit den anderen Christen auf allen Ebenen, innerhalb und außerhalb der Kirche, und versteht ihn ,als Widerspiegelung des Dialogs zwischen Gott und der Menschheit: er geht von Gott aus und wird im göttlichen Logos (dia-logos), unserem Herrn und Retter Jesus Christus, geführt" (\$54). Das Dokument ermutigt Orthodoxe, in einer pluralistischen Gesellschaft vermittelnd zu wirken. Wichtig ist in diesem Zusammenhang eine neue Perspektive auf die Säkularität, die zwar gewiss eine moderne Ideologie ist, aber auch das Potenzial hat, entweder autoritär oder aber gemäßigt liberal zu sein.

Der Autor beschreibt die Aufgabe des Dokuments damit, dass es ein Instrument für das soziale Engagement der orthodoxen Kirche ist, das damit dem Wandel der Welt dienen kann. Besondere Aufmerksamkeit für soziale Themen verdienen zudem besonders jene Orte, in denen die Beziehung zwischen Staat und Kirche de facto anders sind, als sie sich de iure darstellen.

Über diese vier Artikel zum Thema der Nummer hinaus ist ein Beitrag von Jan Dominik Bogataj zu finden. Es geht um den Dialog zwischen Zeitepochen: „Bekehrung als Transformation des Herzens: Guardinis existentielle Interpretation von Augustins Bekenntnissen" bringt - mit Augustin und Guardini - zwei voneinander 
mano Guardini but also the theme of reception which has been one of the leading themes in current ecumenical scholarship and awaits new avenues, also in the patristic inquiry. Augustine is a continuous inspiration in Western thought and Guardini is one of the thinkers highly appreciated by the current Pontiff. Pope Francis' first encyclical Evangelii gaudium addressed Guardini on several occasions and thus brought back to light his slightly forgotten name. The article looks closely at Guardini's fascination with Augustine's Confessions and highlights, in particular, the inner nature of the process of conversion described in the book, Confessions. entfernte Bezugspunkte miteinander ins Gespräch und berührt zugleich die Frage der Rezeption, die eines der zentralen Probleme der Ökumene darstellt und gerade auch in patristischen Untersuchungen neue Zugänge braucht. Augustin ist im Westen unveränderlich von großer Bedeutung, während Guardini einer der Denker ist, die vom heutigen Papst hoch geschätzt werden. Die erste Enzyklika von Papst Franziskus, Evangelii Gaudium, nimmt mehrfach auf Guardini Bezug und bringt dessen Denken wieder neu zum Bewusstsein. Der Autor des Beitrags beschreibt Guardinis Faszination für Augustins Bekenntnisse und besonders für den inneren Prozess der Bekehrung, der in diesem Buch zum Ausdruck kommt. 